\title{
Safe Enough? The Working Lives of New Zealand Children
}

\author{
Danaë Anderson
}

\section{New Zealand Work and Labour Market Institute, Auckland University of Technology}

\begin{abstract}
The experience of New Zealand children in their working lives is a traditionally underresearched area and existing research has been promulgated from the NGO sector (ACYA 2003, CARITAS 2007 \& 2003), with children under the age of 18 recounting their working experiences. Of concern are worrying trends relating to the lack of legislative protection of children, particularly in the areas of minimum age for work and health and safety. Further, key findings are presented from survey and interview data of young adults reflecting on their working lives as children. Working conditions varied widely according to industry type, in which the best working conditions appeared to be those provided by relatives or family friends. While young people were generally positive about their workplace experiences, some dangerous and illegal trends were signposted. These findings challenge the assumptions of the governments and regulatory authorities that children are 'adequately' protected by current legislation and practice.
\end{abstract}

While there continues to be debate regarding New Zealand's ratification of some United Nations (UN) and International Labour Organisation (ILO) protocols relating to protecting children in their working lives, little discourse is evident relating to domestic legislative and monitoring capacity in this concerning area of the labour market. Therefore, the central aim of this paper is to inform discussion on children's work and help identify areas of concern in the working conditions of New Zealand children.

\section{Introduction}

While the welfare of New Zealand adult workers are the primary concern of successive governments and their agencies, the rights of child workers have often been overshadowed. Manifest is widespread belief in most western countries (New Zealand included) that work for children is an appropriate and beneficial passage into the adult world of employment (McKechnie \& Hobbs, 1999, Mizen, Pole, \& Bolton, 2001). Moreover, the perception is conditions of marginalisation, exploitation and mistreatment of child labour occurs only 'overseas' and are rarely encountered in New Zealand. Research also tends to focus on children labouring in developing countries, primarily in service and agricultural sectors and in 'sweatshop labour' (Amin, 1997; Black 1995; Cruz, 1987; Howse \& Tebicock, 1996). The lack of consensus between stakeholders regarding working children begets the question, what are the working experiences of New Zealand children?

The purpose of this paper, therefore, is to draw attention to this largely ignored research area, and to question the working conditions of young workers. Discussion presents key findings from recent survey and interviews with young workers; concentrating on their job experiences, health and safety in the workplace, and knowledge of their employment rights.

\section{Background}

There are disparate opinions regarding the appropriate role of children in work environments, and the issues surrounding children's work continue to be controversial and contentious. Moreover, while child labour is regulated in virtually all countries it continues to flourish worldwide. By the mid1990s, child labour was pronounced by both the ILO and UNICEF to be 'one of the dominant issues of our time' (ILO 2006; 1998; UNICEF 1997), argued as 'perhaps the most visible single issues generating discussion about how children's rights are to be defined and observed in an era of globalisation' (Myers 2001:129).

However, extant research on children's work to date tends to be located in developing countries, and in industries areas that traditionally rely on child labour, such as agriculture, textiles and clothing (Anker \& Barge 1998; Black 1995; White 1996). The assumption is that children are exploited and lack protection (Ahmed 1999; Bequele \& Myers 1995), reiterated in UNICEF's report The State of the World's Children: Focus on 
Child Labour (1997). UNICEF argues that children routinely work in hazardous conditions in all industrialised countries. Most of the world's child labourers operate within the informal labour market, working predominately in small business, agricultural, and horticultural sectors $^{1}$. Given that these sectors have a significant presence in the New Zealand economy and the work sectors are overrepresented in occupational fatality, injury and illness rates, the health and safety of children workers is of great concern (Vocaturo, Kunseler, Slovakova, Ruut, Cavoura, \& Otorepec, 2007).

Mizen, Pole \& Bolton (2001) found children were often chosen as employees because they offered flexible, low-paid labour and maximise employer's profit margins. Such employment often leaves children largely powerless in the employment relationship (Gasson, Gasson, Linzey, \& Powell-Chalmers, $2003,2001)$ as the sectors child workers congregate typically have little or no trade union representation (Anderson, 2010; Barry \& Reddy, 2005). Further, child workers are predominately employed on a casual, parttime, or temporary basis, and many are underprotected by individual or collective agreements. But as an industrialised economy with education and welfare structures, does this situation apply to New Zealand?

\section{New Zealand Research}

Due to the lack of research and inconsistency in data collection and analysis (Cole, 1991; ILO, 2009, 2003; ILO/IPEC-SIMPOC, 2007; IPEC, 2008) there is often uncertainty or disagreement over nature and scope of the supposed 'problem' posed by children working. Discussion internationally, and in New Zealand is limited; as it is unclear the extent of the issue and whether stakeholders should be overly concerned. Because official data on child labour is not routinely collected the statistical information available is difficult to accurately analyse (Roth, 2008b), there is still a paucity of information with most research emanating from non-government sources (Gasson et al, 2003, 2001), and activist organisations (Action for Child and Youth Aotearoa Incorporated (ACYA), 2003; CARITAS, 2007, 2003; CPAG, 2008, 2003).

\footnotetext{
1 Interestingly, agriculture is still New Zealand's primary export industry (The Treasury, 2009). However, the service industry is New Zealand's number one industry in terms of density: $81 \%$ of workers congregate in this area (Callister \& Didham, 2010).
}

In general, research in this area is limited and captures a partial picture of what is actually occurring among child workers (Barry \& Reddy, 2005; Caspi, Moffitt, Wright, \& Silva, 1998; Ehrlich, McClellan, Hemkamp, Islam, \& Ducatman, 2004).

New Zealand employment law also works against child and youth labour in that there is no minimum age for work (as stipulated in the ILO Convention 138), and no minimum wage protection for those below the age of 16 . Such inherent inequalities mean that children are not given the same rights or protection as adults, and often the rights of the child are minimised in New Zealand discourse on workers' rights. The status of New Zealand's child workers is of particular concern given that there is no legislation specifically covering the conditions of children under the age of 16 years (see Employment Relations Act 2000; Health and Safety in Employment Act 1992). While acknowledging that successive New Zealand governments have ratified most United Nations (UN) Conventions pertaining to the welfare of children, the United Nations and, in particular, its Committee on the Rights of the Child has criticised New Zealand's lack of progress towards child labour issues on a number of points:

- New Zealand continues to maintain a reservation of Article 32(2) of the Convention on the Rights of the Children relating to minimum age of access to employment, regulation of hours and work conditions. The Article is to protect children from economic exploitation and risks to their health and safety.

- New Zealand has failed to legislate a minimum wage for child workers under the age of 16 years.

- Children are poorly protected in occupational health and safety matters (for example, there is limited Accident Compensation coverage for child workers ${ }^{2}$ ).

The situation in NZ is that children's work is

\footnotetext{
${ }^{2}$ This is particularly concerning given a large number of children work in the informal labour market and are therefore not covered by Accident Compensation for lost wages. ACC legislation assumes that children's primary activity is attending school, and their wages are not necessary for their own or family's financial wellbeing. For part time and seasonal workers coverage will be further reduced under forthcoming ACC reform (Rail And Maritime Transport Union, 2010).
} 
very loosely regulated, and it is out of step with ILO standards in some areas. But 'there are real practical, social, and political obstacles in the way of raising standards' (Roth, 2008a: 4), and legislation largely fails to regulate working terms and conditions for children as a distinct group from adults.

\section{Profile of New Zealand child workers}

Most research emanates from nongovernment sources (Caspi et al, 1998; Gasson et al, 2003), and activist organisations (ACYA, 2003; CPAG, 2008, 2003; CARITAS, 2007, 2003). Some quantitative analysis focuses on either certain industries or relies on incomplete and unreliable government statistics or survey methods, and the incomplete statistical information available is difficult to analyse (Roth, 2008a). Therefore, in general, research in this area is limited and often fails to capture what is actually occurring amongst child workers (Barry \& Reddy, 2005; Bradford, 2007; Caspi et al, 1998; Gasson et al, 2003; Goddard \& White, 1982: 466; Ehrlich et al, 2004).

Nonetheless, research indicates that child workers are typically found in family-run businesses, in the primary sector (agriculture, horticulture, etc) as well as the retail and hospitality industry sectors. Children also constitute a significant part of the informal labour market in both overseas and $\mathrm{New}$ Zealand "... often working for very low wages and at times in dangerous and/or illegal working conditions" (CARITAS, 2003:11). Moreover, this group of workers is frequently vulnerable to exploitation for two reasons. First, they are not covered by protective employment legislation that legislates a minimum age for work, minimum wages for those below 16, or encompassing health and safety standards. Second, they are often an 'invisible' segment of the labour force and thus are largely ignored in statistical reporting and analysis.

There is anecdotal speculation that with the types of jobs and businesses children congregate in, they are more likely not to report their injuries, or are 'encouraged' not to report, and injuries may be attributed to nonwork accidents as a way of avoiding increased accident compensation (ACC) premiums. There is also a lack of detail; that is, there is often little or no information on the ethnicity of the injured child worker or under what circumstances the accident occurred (Lilley, Feyer, Langley \& Wren, 2004). Thus ACC figures provide only a partial picture, covering those injuries that were officially reported or led to compensation claims. To date the Department of Labour appears to have not placed particular emphasis on monitoring children in workplaces, and there is little information relating to this sector, including breaches of $\mathrm{OSH}$ regulations.

\section{Research Methodology}

There is also some quantitative analysis that focuses on either certain industries, geographic location, or relies on incomplete government statistics (see ACC, 2006; Pugh, 2007). However, to make use of partial information is necessary to see the 'gaps' that manifest in findings and analysis. Numerous complexities arise in the theory and practice of children's work. The intricacy of issues presents numerous methodological challenges, exacerbated by the lack of consensus on definitions related to children's work and interrelated subjects (see Ashagrie, 1993; Barwick, 2006; Bequele \& Myers, 1995; ILO/IPEC-SIMPOC, 2007; Marlenga, Berg, Linneman, Brison, \& Pickett, 2007).

The dominant form of methodology applied while researching children's work experiences in New Zealand is qualitative, concentrating mainly on the social implications in this area and detailing children's experiences, as illustrated by the CARITAS reports Protecting Children at Work: Children's Work Survey (2003) and Delivering the Goods: A Survey of Child Delivery Workers (2007). In order to gain a more complex understanding of what is actually occurring in New Zealand a triangulated methodological approach using multiple data collection methods was used. Research collected survey and interview data of policymakers, employee and employer groups, government departments, nongovernment organisations, and, most importantly, young people. Interview and surveying data will be discussed in the following section.

\section{Research Process and Key Findings}

Stages II \& III: Surveying and Semi-structured Interviews by Young Adults Reflecting on their Experiences as Working Children.

Stage II comprised of surveying young adults (25 years and under) reflecting on their working experiences as children. In order to capture recent and a wide range of experiences, an ethnically diverse, young 
population was targeted. A university environment was ideal to 'capture' this cohort due to the number and variety of young students, as well as pragmatic considerations. Therefore, students at Auckland University of Technology were invited to complete an anonymous survey, the only identifiers being gender, age and ethnicity. The number of usable survey responses was $n=159$.

\section{Survey Participant Characteristics}

There were a total of 54 male and 105 female participants $(n=159)$, the gender breakdown correlating with Education Ministry (2009) findings that two thirds of university students are female. There was also a wide variety of ethnicities represented, indicative of Auckland having the greatest diversity of all main cities in New Zealand (Statistics 2009). Unlike previous studies (in particular CARITAS, 2007, 2003), no survey respondents had been in paid employment before the age of ten, outlined in Table 1. In fact, a majority of respondents began paid work around 15 years of age. A majority of respondents (119, or $74.8 \%$ ) had not worked for family or friends, inconsistent with other literature in this area. One could speculate on the probable reasons, for example, socioeconomic background, survey sample, or ethnicity. However, any 'links' would be interpretive and ambiguous, as greater sampling would be required to draw definitive conclusions.
Table 1: Age when starting first job

\begin{tabular}{|l|l|}
\hline Age of first job & Number \\
\hline 10 & 5 \\
\hline 11 & 0 \\
\hline 12 & 9 \\
\hline 13 & 10 \\
\hline 14 & 23 \\
\hline 15 & 50 \\
\hline 16 & 36 \\
\hline 17 & 26 \\
\hline Total & 159 \\
\hline
\end{tabular}

\section{Job characteristics}

Respondents were asked to list all jobs they worked in until the age of 18 , the responses

together with the types

grouped into sectors

of work. The range and types of jobs undertaken by respondents were typical of those documented in other studies of children's work in developing and developed countries. Typically the jobs were located in the service and agriculture sectors, but there was an extremely diverse range of occupations (see Table 2 below).

Table 2: Types of Work

\begin{tabular}{|c|c|}
\hline Job category & Types of work \\
\hline Manual labour & $\begin{array}{l}\text { house painter, labourer, tiling, golf course maintenance, maintenance for a hire firm, } \\
\text { light labouring, bulldozer operator }\end{array}$ \\
\hline $\begin{array}{l}\text { Agriculture/ } \\
\text { horticulture }\end{array}$ & $\begin{array}{l}\text { tomato packing, hothouse work, vet assistant, agricultural production, stable hand, } \\
\text { milking cows, strawberry picking, zoo, tree maintenance }\end{array}$ \\
\hline Administration & receptionist, office administration, advertising accounts, data entry \\
\hline Retail & $\begin{array}{l}\text { gift shop, video shop, Lotto, clothing, electronics, checkout operator, fast food, travel } \\
\text { bookings, cashier }\end{array}$ \\
\hline Food & bakers apprentice, waitress, butchers assistant, barista, cook, kitchen hand \\
\hline $\begin{array}{l}\text { Instruction/ } \\
\text { children }\end{array}$ & $\begin{array}{l}\text { swimming instructor, dance tutor, babysitting, sports referee, coach, English teacher, } \\
\text { camp counsellor, sailing instructor, day care centre }\end{array}$ \\
\hline Hospitality & bar waitress, bartender, pub work, movie guide events company, delivery driver \\
\hline $\begin{array}{l}\text { Health and } \\
\text { beauty }\end{array}$ & $\begin{array}{l}\text { dental assistant, lab assistant, caregiver, makeup artist, hairdresser, beautician, } \\
\text { AVON representative }\end{array}$ \\
\hline Other & $\begin{array}{l}\text { family business (resort, race car production), engineering apprentice, cleaning, paper } \\
\text { round, factory work, housecleaning, computer repairs, car groomer, busboy, shelf } \\
\text { stacker, milk delivery }\end{array}$ \\
\hline
\end{tabular}


Stage III consisted of interviewing young workers face-to-face using a semi-structured interview schedule (Bryman \& Bell, 2003), designed to elicit information on their working experiences as children. Selection criteria required respondents had:
- recent experience of work as a child

- ability to recall specific details of their experiences

- paid work in a diverse range of workplaces and experiences.

Table 3: Interview Sample Characteristics

\begin{tabular}{|l|l|}
\hline Respondent A & New Zealand born European male, aged 19 \\
\hline Respondent B & Singapore born, Chinese female, aged 25 \\
\hline Respondent C & Fijian born, Indian male, aged 22 \\
\hline Respondent D & New Zealand born European female, aged 20 \\
\hline Respondent E & New Zealand born European male, aged 22. \\
\hline
\end{tabular}

\section{Discussion}

\section{Health and Safety of Child Workers}

Accident Compensation Corporation 2006 figures show that health and safety outcomes for young workers are poorer when compared to adult workers, both in terms of injury rates and the lack of protection in many workplaces. Examples of poor, hazardous working conditions outlined in the survey responses include workers being left in sole charge with little or no training or supervision and working beyond the legal hours of work for youth. Moreover, while the survey sample is small the findings point to some disturbing working conditions for youth in which they are placed in hazardous conditions with little or no supervision and training, contravening the Health and Safety in Employment Act 1992. The survey asked whether the respondent had ever felt unsafe in any of their workplaces, and if so why?

While $16 \%$ of respondents had felt that they worked in unsafe workplaces, the reasons were varied and in some instances extremely worrying, indicating employers are not identifying, managing and identifying hazards as they are required to do under the Act regulations. Experiences included:

- Working late nights by myself in Queen St, weirdos would sometimes come in'

- 'Working by myself out in Westgate. Dodgy people came in'

- 'He (boss) slapped my ass and swore every five minutes'.

- 'Was targeted by a manager and verbally abused'
- 'Shoplifting, drunken men (different jobs')

- 'Having to work late and find transport home'

- 'When our shop was robbed'

- 'Carrying large amounts of cash in a crowded place'.

The survey also highlighted issues around physical safety of young workers, including a lack of supervision and insufficient hazard protection as well as harassment, particularly prevalent for women:

- Having to serve alcohol to drunk people, in my religion [that has] no drinking. Also men trying to touch me and laughing'

- 'Some jobs I had to do I knew weren't safe'

- 'Dodgy bar and often left on my ownwas very young at the time'.

Some Stage III respondents also indicated feeing unsafe in their workplaces:

- Respondent A: 'Sometimes dogs, when it was late in winter...'

- Respondent C: 'All the time in warehouse... Heavy stuff, people lifted them (boxes) to fast cos they want to get it done. But you think it's funny when you're a guy... maybe young so you don't know.'

- Respondent E: 'I guess on the wharf is quite a scary place. There was large cranes driving around, and the 
wharfies always tell you stories about people getting their legs crushed...people dying, having to get the blood and stuff out from under the crane. Yeah, so I was probably a bit nervous at times. Health and safety? No, not really. I mean the first time I went down there, um, it was with another employee... he said to watch out for the cranes' (laughs).

Respondents at both Stage II and III commented on the high level of noncompliance and lack of enforcement of the regulations controlling the hours of work and the number of breaks to which youth workers are entitled (Occupational Health and Safety, 2009). Further, some respondents recounted their experiences of unsafe workplace conditions, such as heavy lifting, the use of dangerous equipment, and being exposed to physical workplace hazards. For example:

- I was a builder for a few years, and there were many times when I was working up on a roof or working with dangerous tools when I felt unsafe' (Male, aged 22).

\section{Workplace Injuries}

Survey respondents were asked whether they were injured while at work and their employer's response. In total, over a fifth of the respondents recalled having an accident while working and a number of injuries went unreported to the appropriate government agencies. The findings regarding the employer's responses typically fell into three categories:
1) total compliance
2) partial compliance; and
3) non-compliance.

Total compliance equated to the employer recording the accident and ensuring the employee had appropriate medical treatment and compensation. Of concern, only $11.8 \%$ of respondents reported that their employer had fully complied. Partial compliance was the most common response $(87.06 \%)$ in which the injured worker was taken to the local doctor, but neither ACC nor the Department of Labour were notified of the injury. As ACC was not notified and the injury unrecorded, medical bills and compensation could not be claimed by the worker. Of greatest concern is the (admittedly small, 7 respondents) number of employers who chose to breach legal obligations. Some examples were:

- $\quad$ 'Recorded it BUT they just ignored my main accident and weren't concerned. BAD EMPLOYER!!'

- 'Cut hand on glass washing dishes. Boss sent me home. Had to get stitches and miss work for two weeks with no pay'

- 'Wrote in an accident form when I asked her to fill one out. She laughed at the situation and I filled one out for myself'

- 'Cut my hand in the slicer... It bled everywhere... felt really sick. Went to the supervisor and she bandaged (the injury). It kept bleeding so she sent me home. Had to go to after hours, doctor said was lucky I didn't sever the nerve. Had two weeks off- no pay.'

- 'Yelled at me and gave customer a new shirt and free drink as I got my blood on it'

- I felt unwelcome back at the job as I claimed ACC'

Further, only two of the face-to-face interviewees were aware of how New Zealand's universal non-faults compensation scheme (ACC) operated or whether or not a claim had been lodged on their behalf when they were injured. One was aware because of involvement in sports, but didn't link the scheme to the workplace (Respondent $\mathbf{C}$ ). Respondent $B$ became aware following injury at work:

- 'I got hit with a tyre iron when I was working in my second job. And I had two weeks off work. And the second week I got ACC. The doctor explained it to me (not my boss). I don't think they (the employer) knew about it to be honest. It was quite an amateur operation really.'

Findings mirrored Pugh's (2007) research indicating poor knowledge of rights and obligations relating to workplace safety. However, in New Zealand there is no compulsory education programme in schools mandated through legislation, discussed in the following section.

\section{Knowledge of Employment Rights}


While there were no questions directly relating to knowledge of employment rights in Stage II surveying, Stage III interviewing covered this area in more detail. There was mention of a lack of knowledge from all respondents, consistent with the concerns of some key stakeholders (particularly in the NGO sector). None of the respondents were aware of their rights and responsibilities as employees, such as holiday pay, or giving notice when sick. However, Respondent B did comment that her parents had instilled in her a work ethic, stating:

'My parents educated me that you had to be responsible, if you had a job you had to go. My mentality was that if I don't go to work I don't get paid so I best turn up and get my money!'

Respondents were asked if they knew about legislation covering:

1) minimum age for work

2) minimum wage

3) health and safety.

All $(100 \%)$ answered no to all three areas, although Respondent $\mathbf{C}$ on the factory site was given a hard hat and reflector vest (but at under 16 was breaking the law driving forklifts!). Respondent E found out the agesetting of the minimum wage when he was told that as he was under 16 he'd be getting "below that". Three respondents had a written employment contract while two did not, consistent with Pugh's 2007 research, where only 49 percent of respondents were covered by a written agreement. Youth Law also reports the continuing proliferation of verbal, casual employment agreements (despite the provisions of the ER Act requiring otherwise)' (Hancock, 2009: 1). However, of the three who had written agreement, not one had not read their terms and conditions:

Respondent A: 'Was only young, my mum read it I think'.

Respondent C: 'They gave it, and I just signed it. Didn't know what to expect, look for.'

Respondent E: 'Nah just signed it'.

\section{Workplace power?}

In general, children are able to exert little leverage on the conditions they are offered and occupy a position at the periphery of the labour market (Anderson, Lamm, Shuttleworth, McMorland \& Rasmussen, 2008; Atkinson, 1984; Forastieri, 2002). Therefore, they are directly and often adversely affected by the reduction in the 'state's role in labour relations as well as the legal protections offered to workers individually and collectively' (Buchanan \& Nicholls, 2003: 2). To complicate matters, the level of legal protection and work entitlements for young worker varies considerably in New Zealand and is based entirely on the age of the worker - that is, adult workers are afforded more protection and have access to more entitlements (bonuses, training, etc) while children and young workers are frequently omitted (Boyden, Ming and Myers, 1998; Greenberger \& Steinberg, 1986; Myrstad 1999). For a significant number of respondents their first working experience had been working for family or friends of the family (24.5\%, or 40 people), although 119 (74.8\%) had not. However, those that had worked for family members were overall more likely to record positive experiences, perceptions of fairness and safety, and higher pay if they were employed by their relatives, and were generally happier in their employment.

In contrast, of particular concern were feelings of marginalisation and unfairness in work environments of the respondents and interviewees. In addition, while the variation in students manifested in diverse working experiences, common themes and concerns were identified relating to job types, equity issues, and workplace safety. In particular, respondents typically recalled their working years as a child or youth as having some or all of the following elements:

- unfair and inequitable wages, no opportunity to progress in the business and a general feeling of not being valued as a worker;

- working in unsafe conditions, often suffering from a work-related injury or illness, and feeling threatened and scared;

- the lack of compliance with basic employment legislation, such as the Employment Relations Act, 2000; Health and Safety in Employment Act, 1992; and the Human Rights Act, 1993.

However, an overwhelming number of respondents (over $91 \%$, or 146 out of 159 respondents) stated that their earlier working experience was a positive one. There are, 
however, a number of contradictions, where on one hand some respondents found their working experiences extremely positive, gaining skills and new networks, while others felt exploited by their employers and vulnerable in their workplaces. Still others contradicted themselves when answering the survey questions. For example, when answering the final question: "What other aspects of the job did or didn't you like?" $(n=106)$, only six answered positively (2 with provisos where they liked the position but not the management). Therefore, 100 respondents (or 94.3 percent) gave negative responses about their work, despite saying that work overall was a positive experience. This inconsistency is puzzling, and suggests that while work is seen as positive in retrospect the conditions experienced were more often that not poor.

The general view appears to be that work is positive for children and improved human capital qualities may facilitate positive employment outcomes in the future (Caspi et al, 1998; DoL, 2009). In contrast, this study signpost worrying trends, conflicting with the government's policy-making assumption that children are 'adequately protected'. Noncompliance with basic employment law highlighted in this and other studies continue to undermine the wellbeing of young workers. The study also raises a number of questions, for example, to what extent do young workers gain tangible, transferable skills, or is the work dangerous and tedious? What is the appropriate level of legislation and protection for young workers?

\section{Concluding comments:}

It is evident that children working in New Zealand is seen as a rite of passage and appropriate preparation for a working life as an adult. Yet in spite of successive governments' contention that New Zealand's laws covering working children are "adequate" there is growing evidence that the current protective legislation is insufficient and that there is a general lack of regulatory enforcement and compliance. The employment legislation has inherent inequalities in that children are not given the same rights or protection as adults.

This research identifies that children lack sufficient coverage in and knowledge of their health and safety and employment rights and as a result are extremely vulnerable to dangerous and/or illegal working conditions. Moreover, the power imbalance evident in their working relationships means their ability to affect and improve working conditions is constrained. Further questions must be asked of what suitable work is for young people and the appropriate level of regulation so children can work in safe employment conditions.

\section{References}

Accident Compensation Corporation (2006). ACC Injury Statistics 2006, Section 3.1: All Work-Related Claims. Retrieved 13 July, 2008, from

http://www.acc.co.nz/about-acc/acc-injury-statistics-2006/SS WIM2 062980

Action for Child and Youth Aotearoa Incorporated (ACYA) (2003, March). Child and Youth in Aotearoa 2003: The Second non-governmental organisations; report from Aotearoa New Zealand to the United Nations Committee on the Rights of the Child. Wellington: ACYA.

Ahmed, I. 1999. Getting rid of child labour, Economic and Political Weekly, 34(27): 1815- 22.

Amin, S. (1997). Capitalism in the Age of Globalisation. London: Zed Books Limited.

Anderson, D. (2010). Safe Enough? The Working Experiences of New Zealand Children. (Masters thesis). Auckland: Auckland University of Technology.

Anderson, D., Lamm, F, Shuttleworth, P., McMorland, J., \& Rasmussen, E. (2008, 11 December). Child Labour: What is Happening in New Zealand? Paper presented at the 2008 Labour Employment and Work Conference, Wellington.

Ankar, R. \& Barge, S. 1998. Economics of child labour in Indian industries. Geneva: ILO Ashagrie, K. (1998). Statistics on Child Labor and Hazardous Child Labor in Brief. Geneva: ILO Atkinson, J. (1984, August), Manpower Strategies for Flexible Organisations. Personnel Management, 28-31.

Barry, C., \& Reddy, S. (2005, 25 August). International Trade and Labor Standards: Draft 1.60.

Retrieved 8 August, 2008, from http://organizations.lawschool.cornell.edu/ilj/symposium/papers/just linkage.pdf 
Barwick, H. (2006, April). Youth work today: a review of the issues and challenges. Wellington: Ministry of Youth Development.

Bequele, A., \& Myers, W.E. 1995. First things first in child labour: eliminating work detrimental to children. Geneva: ILO.

Black, M. 1995. In the Twilight Zone: Child Workers in the Hotel, Tourism and Catering Industry. Geneva: ILO

Boyden, J., Ling, B., Myers, W. (1998), What Works for Working Children, Rädda Barnen \& UNICEF: Stockholm

Bradford, S. (2007, 21 November). Full review of Child Labour Laws needed [Press release]. Wellington: The Green Party.

Bryman, A., \& Bell, E. (2003). Business Research Methods. Oxford \& New York: Oxford University Press.

Buchanan, P.G., \& Nicholls, K. (2003). Labour Politics in Small Open Democracies: Australia, Chile, Ireland, New Zealand and Uruguay. Hampshire; New York: Palgrave MacMillan.

Callister, P., \& Didham, R. (2010). Workforce composition - Changing industries. Te Ara - the Encyclopedia of New Zealand. Retrieved January 12, 2010, from http://www.TeAra.govt.nz/en/workforce-composition/3

Catholic Agency for Justice, Peace and Development (CARITAS (2007). Delivering the Goods: A Survey of Child Delivery Workers. Thorndon: CARITAS.

CARITAS (2003). Protecting Children at Work: Children's Work Survey. Thorndon: CARITAS.

Caspi, A., Moffitt, B., Wright, B., \& Silva, P. (1998). Early failure in the labour market: child and adolescent predictors of unemployment in the transition to adulthood. American Sociological Review, 63, 424-451.

Child Poverty Action Group (CPAG) (2008). Income assistance policy discriminates against children: CPAG's Human Rights legal case (2008). Retrieved August 30, 2008, from http://www.cpag.org.nz/campaigns/Child_Tax_Credit_IWP.html

Child Poverty Action Group (CPAG) (2003). Our Children: The Priority for Policy (2 ${ }^{\text {nd }}$ ed.). Auckland: Child Poverty Action Group.

Cole, P. (1991). Children at Work: Peril or Promise? Albany, New York: AFL-CIO.

Cruz, L.A. (1987). Child labour in the hotel, catering and tourism sector in the Philippines. Geneva: unpublished ILO paper.

Department of Labour (DoL) (2009). Youth in the New Zealand Labour Market: National Monitoring Series. Wellington: Department of Labour.

Ehrlich, P.F., McClellan, W.T., Hemkamp, J.C., Islam, S.S., \& Ducatman, A.M. (2004, May).

Understanding work-related injuries in children: a perspective in West Virginia using the statemanaged workers' compensation system. Journal of Paediatric Surgery, 39(5), 768-772.

Forastieri, V. (2002) Children at Work: Health and Safety Risks. Geneva: ILO.

Gasson, R., Gasson, J., Linzey, T., \& Powell-Chalmers, J. (2003). Young People and Work. Dunedin: Dunedin College of Education.

Gasson, R., Gasson, J., Linzey, T., \& Powell-Chalmers, J. (2001). Children and Work. Dunedin: Dunedin College of Education.

Goddard, V., \& White, B. (1982). Child Workers and Capitalist Development: An Introductory Note and Bibliography, Development and Change, 13.

Greenberger, E., \& Steinberg, L. (1986). When Teenagers Work: The Psychological and Social Costs of Adolescent Employment. New York: Basic Books.

Hancock, J. (2009, 17 April). Submission of YouthLaw Tino Rangatiratanga Taitamariki and Action for Children and Youth Aotearoa Inc on Children, Young Person and Their Families (Youth Court Jurisdiction and Orders) Amendment Bill. Retrieved 18 July, 2009, from

http://www.acya.org.nz/site resources/library/Documents/Submissions/CYF ( Court Jurisdic tion) Bill.pdf

Howse, R., \& Tebicock, M.J. (1996). The Fair Trade Free-Trade Debate: Trade, Labour and the Environment. , International Review of Law and Economics, 16, 61-79.

International Labour Organisation (ILO) (2009a). Child Labour Statistics. Retrieved February 9, 2009, from

http://www.ilo.org/dyn/clsurvey/lfsurvey.home

ILO (2006). The end of child labour: Within reach. Geneva:ILO.

ILO (1998). Conference Report VI (I) Child Labour: Targeting the Intolerable. Geneva: ILO.

ILO/IPEC-SIMPOC (2007). Towards an internationally accepted statistical definition of child labour: children's activities and their definitions. Geneva: ILO.

International Programme on the Elimination of Child Labour (IPEC) (2008). Hazardous Child Labour. 
Retrieved October 11, 2008, from

http://www.ilo.org/ipec/facts/Hazardouschildlabour/index.htm

Lavalette, M. (1994). Child Employment in the Capitalist Labour Market. England: Avebury.

Lilley, R., Feyer, A., Langley, J., \& Wren, J. (2004, 21 May). The New Zealand child work-related fatal injury study: 1985-1998. The New Zealand Medical Journal, 117(1194). Retrieved October 6, 2009 , from http://www.nzma.org.nz/journal/117-1194/891/

Marlenga, B., Berg, R., Linneman, J., Brison, R., \& Pickett, W. (2007, February). Changing the Child Labor Laws for Agriculture: Impact on Injury. American Journal of Public Health, 92(2), 276282.

McKechnie, J, \& Hobbs, S. (1999, February). Child Labour-The View from the North. Childhood- $A$ Global Journal of Child Research, 6(1), 89-100.

Mizen, P., Pole, C., \& Bolton, A. (2001). Hidden Hands: International Perspectives on Children's Work and Labour. London: Routledge Palmer.

Myers, W.E. (2001). Valuing diverse approaches to child labour. In Lieten, K., \& White, B. (2001). Child Labour Policy options. Amsterdam: Aksant Academic Publishers

Myrstad, G. (1999, February). What can trade unions do to combat child labour? Childhood- A Global Journal of Child Research, 6(1), 75-88.

Occupational Health and Safety (2009). Young Workers Fact Sheets: Youth Age Restrictions on Dangerous Work. Retrieved 6 January, 2009, from http://www.osh.dol.govt.nz/publications/factsheets/youth-age-restrictions.pdf

Pugh, J.A. (2007, October). Health and Safety Knowledge of Young Workers: a Study of Schoolaged, Part-time Workers in the Taranaki Region. Wellington: Department of Labour.

Rail and Maritime Transport Union (2010, 12 February). National's ACC Cuts Will Rip Off Workers [press release].

Roth, P. (2008a). The difficulty in regulating child labour in developed countries: A New Zealand Perspective. Paper presented at International Conference on Child Labour and Child Exploitation. Cairns, August 2008.

Roth, P. (2008b, 27 March). Child Labour in New Zealand: a job for the nanny state? Retrieved June 15,2008 , from http://www.nz-lawsoc.org.nz/lawtalk/708Roth.html

UNICEF (1997). The state of the world's children. Oxford: Oxford University Press

Vocaturo, E., Kunseler, E., Slovakova, G., Ruut, J., Cavoura, O., \& Otorepec, P. (2007, May 8).Work injuries in children and young people. Bonn: European Environment and Health Information System.

White, B. 1996. Globalization and the child labour problem. The Hague: Institute of Social Studies, Working Paper Series No. 221.

\section{Legislation}

Employment Relations Act 2000 (New Zealand).

Health and Safety in Employment Act 1992(New Zealand).

Human Rights Act 1993/ Amendments 2001(New Zealand

ILO Convention 138: Minimum Age Convention 1973 (Member States).

United Nations Convention on the Rights of the Child (UNCROC) 1989 (Member States) 
